\title{
$\breve{S}$ T Ú D I E
}

\section{K JAZYKU MIESTNEJ SPRÁVY PODL'A STAROSLOVIENSKEHO PREKLADU NOMOKÁNONA}

\author{
RÓBERT J Á GE R - MIROSLAV LY S Ý
}

\begin{abstract}
JÁGER, Róbert - LYSÝ, Miroslav. On the language of local administration according to the Old Slavonic translation of the Nomokanon. Historický časopis, 2019, 67, 3, pp. 413-437, Bratislava.

In the paper we try to reconstruct the system of local administration in Mojmír's Moravia. We start from the assumption that the terms used in the Old Slavonic translation of the Nomokanon to designate units in the ecclesiastical administration probably reflected the terms used in local administration in the language of the time. Attention is devoted to units designated as oblastь, strojenije, predělъ, gradъ, město, vbsь, strana. Then we try to identify these territorial units in the system of local administration, their place in the supposed hierarchical structure with a hypothetical description of their organization.
\end{abstract}

Key words: Nomokanon. Ecclesiastical administration. Public administration. Methodius. Terminology. Old Slavonic.

DOI: https://doi.org/10.31577/histcaso.2019.67.3.2

Arcibiskup Metod sa v roku 873 vrátil zo zajatia. Na Morave ho privítal knieža Svätopluk (871 - 894) a odovzdal mu do správy kostoly a klerikov „na všetkých hradoch". ${ }^{1} \mathrm{Z}$ letmej a historikmi hojne citovanej zmienky Metodovho hagiografa sa odvodzuje, že hrady predstavovali základ mojmírovskej miestnej správy. Pod hradom sa pritom nemusel mysliet' len samotný hrad ohraničený opevnením, ale aj k nemu priliehajúce okolie. ${ }^{2} \mathrm{~V}$ Živote Metoda nemáme informáciu, ako konkrétne vyzerala správa gradu a kto stál na jej čele. Môžeme sa len domnievat', že na čele niektorých hradov vo vnútri mojmírovskej domény stáli pravdepodobne župani a v iných hradoch sídlili pravdepodobne druhostupňové kniežatá. ${ }^{3}$ Ostat-

1 Žitije Mefodija, c. 10. In Magnae Moraviae Fontes Historici II. Textus biographici, hagiographici, liturgici. Eds. Dagmar Bartoňková et al. Brno: Universita J. E. Purkyně, 1967 (d’alej MMFH II), s. 154.

2 Takúto predstavu formuloval SOKOLOVSKÝ, Leon. Grad - španstvo - stolica - župa (Príspevok k terminológii dejín správy). In Slovenská archivistika, 1981, roč. 16, č. 2, s. 94-117.

3 STEINHÜBEL, Ján. Hrady a župani na Vel'kej Morave, v Chorvátsku, v českých krajinách 
né starosloviensky písané pamiatky však obsahujú pomerne vel'ký rozsah termínov, ktoré by sme mohli vztiahnut' k miestnej správe a ich rozbor je predmetom predkladanej štúdie.

V súvislosti s mojmírovskou miestnou správou si môžeme klást' dve navzájom súvisiace otázky. Tou prvou je, aké d’alšie termíny sa používali na Morave pre označenie jednotiek miestnej správy. Druhou otázkou potom pochopitel'ne je, nakol'ko efektívny mohol byt' výkon takejto správy. Inými slovami, nakol'ko centralizovaný mohol byt' mojmírovský útvar a ako efektívne dokázali mojmírovské kniežatá ovládat' územia, pokial' na nich neboli priamo prítomní.

Na prvú otázku sa odpovedá omnoho l'ahšie ako na druhú, ak uvážime, že o lokalitách, ktoré nepatrili k hlavným centrám mojmírovskej Moravy, máme vlastne len vel'mi kusé správy. Nedokážeme s istotou povedat', ako sa nazývalo hlavné sídlo Mojmírovcov a z ich hradov poznáme po mene len Devín (864), Nitru (podl'a Conversia a Industrię tuę) a Bratislavu (907). Zhodou okolností sa tieto tri lokality nachádzajú na Slovensku. O ostatných hradoch vieme prostredníctvom archeologických výskumov, nemáme však istotu, ktoré z týchto hradov ešte boli súčast'ou mojmírovského panstva, a ktoré už nie. ${ }^{4}$

Vzhl'adom k tomuto množstvu otázok bude užitočné, ak sa pozrieme na dosial' prehliadaný starosloviensky text, ktorým je starosloviensky preklad Nomokánonu. Jeho cyrilikou písané rukopisy sa dnes nachádzajú v Moskve a z viacerých variantov Nomokánonu sa zdá, že prvotný Metodov preklad (ktorého rukopis sa samozrejme nezachoval) vychádzal zo Scholastikovej Synagoge. ${ }^{5}$ Rozsah Nomokánonu, jeho jazykový ráz i prípadný účel dávajú tušit', že ide o najmladší právny text z obdobia pôsobenia byzantskej misie. ${ }^{6} \mathrm{Aj}$ preto je však terminologicky zrejme bližší domácemu prostrediu ako ostatné juridiká. Navyše je textovo vel'mi rozsiahly; obsahuje viac ako dvanást'tisíc slov. Bohatost' tohto textu v porovnaní s ostatnými staroslovienskymi prameňmi však prekrývajú oprávnené pochybnosti o jeho používaní vo vtedajšej spoločnosti. Aj preto je

a v Uhorsku. In Stredoveké hrady na Slovensku. Život, kultúra, spoločnost'. Ed. Daniela Dvořáková. Bratislava: Veda; Historický ústav SAV, s. 30. ISBN 9788022416085

4 V minulosti sa mojmírovskou miestnou správou zaoberali viacerí autori. Lubomír HAVLÍK (Morava v 9. a 10. století. K problematice politického postaveni, sociální a vládní struktury a organizace. Praha: Academia, 1978, s. 68-71) pripúšt’a existenciu žúp na Morave (podobne však aj v Uhorsku a oba príklady sú z terminologického hl’adiska nevhodné). Najnovšie tiež STEINHÜBEL, ref. 3, s. 27-30.

Z hl'adiska vzt'ahu archeologických a historických prameňov pre obdobie medzi 9. storočím a arpádovským obdobím je najnovším pokusom o interpretáciu práca HUDÁČEK, Pavol. Castrum Salis. Severné pohraničie Uhorska okolo roku 1000. Bratislava: Veda, 2017. ISBN 9788022415354.

5 PAVLOV, A. S. Pervonačal’nyj slavjano-russkij Nomokanon. Kazaň: V univ. typ., 1869.

6 KIZLINK, Karel. Právo Vel'kej Moravy. In Právnické štúdie, 1969, roč. 17, č. 3, s. 433-490. 
Nomokánon pamiatka, pri ktorej skôr ako dobové normy môžeme analyzovat' jeho názvoslovie.

Pri tejto analýze budeme vychádzat' z hypotézy, že územné jednotky cirkevnej správy sa vytvárali tak, že kopírovali územné jednotky miestnej správy. ${ }^{7} \mathrm{Aj}$ preto termíny obsiahnuté v Nomokánone slúžiace na označenie jednotiek cirkevnej správy by mali zároveň označovat' aj územné jednotky miestnej správy Vel'kej Moravy. Uvedené konštatovanie môžeme formulovat' aj opačne: pôvodné označenie územných jednotiek miestnej správy bolo pravdepodobne prebraté arcibiskupom Metodom pri preklade Nomokánona a týmito pôvodnými termínmi boli označované aj územné jednotky cirkevnej správy.

Hoci z Nomokánonu sa nedajú identifikovat' spôsoby organizácie moci v lokálnych centrách, predsa sme schopní aspoň systematizovat' jej terminológiu a v hrubých rysoch sa môžeme pokúsit' určit hierarchickú štruktúru týchto územných jednotiek. $\mathrm{V}$ tomto prípade si pomôžeme aj porovnaním s d’alšími starosloviensky písanými pamiatkami. ${ }^{8}$

\section{Termíny oblastb, strojenije, eparchija}

Nasledujúca tabul'ka obsahuje prehl'ad použitia termínov strojenije, oblastb a eparchija v staroslovienskom texte Nomokánona.

Výraz

na svęštenije i strojenije

strojenija ...choditi
Význam

(za účelom) svätenia a spravo- Nk I, 246 vania

prechádzat' hranice (diecézy) Nk III, 246

7 Takto vyzeral napríklad vzt’ah komitátnej a cirkevnej správy v Uhorsku. Porovnaj STEINHÜBEL, Ján. Nitrianske kniežatstvo. Počiatky stredovekého Slovenska. Bratislava: Rak, 2016, s. 391-400. ISBN 9788085501643.

8 V prípade, že predmetný termín obsiahnutý v Nomokánone je obsiahnutý aj v inom normatívnom texte z 9. storočia, uvádzame informáciu o tejto skutočnosti v príslušnej časti tejto práce. Vo všeobecnosti však možno konštatovat', že množstvo termínov slúžiacich na označovanie jednotiek (miestnej) správy obsiahnutých v ostatných normatívnych textoch vel'komoravského obdobia je minimálne. Ustanovenia svätých otcov obsahujú len dva termíny, ktoré možno priamo alebo nepriamo použit' na označenie jednotiek správy: oblastb a otčestvo. Porovnaj Zapovědi svętyichъ otьсь 1. In Magnae Moraviae fontes historici IV. Leges, Textus iuridici, Supplementa. Eds. Dagmar Bartoňková et al. Brno: Universita J. E. Purkyně v Brně, 1971 (d’alej MMFH IV), s. 138. Súdny zákon pre l’ud obsahuje tieto termíny: selo (čl. 1, čl. 15), zemla (čl. 4, čl. 21), oblastb (čl. 8), gradb (čl. 15, čl. 21), město (čl. 22), žjupanъ (čl. 3), kmetb, (čl. 3, 7a). Porovnaj Zakonъ sudnyi ljudьmъ 1, 3-4, 7a, 8, 15, 21-22. In MMFH IV, s. 178, 180-181, 184-185, 187, 191. Napomenutia vladárom obsahuje: zemla (čl. 1), vladyka (opakovane v texte), knjazъ (opakovane v texte). Porovnaj Vladykam zemlę Božie slovo velitъ. In MMFH IV, s. 199-204. 
čress strojenije...choditi

na ina strojenija

o strojeniichb

strojenije c [b]rk[ъ]vbnoje

ljudbskaja strojenija

jeparchi-i

vъ kojeiždo eparchii

vъ kojeiždo jeparchii

vbschyčšati oblasti inogo

vb oblasti

vo vsękoi oblasti

oblastbnyi sborz

vъ svojei oblasti

jedinu oblastb

$v ъ$ jedinoi oblasti

kromě svojeja oblasti

vъ oblasti jego

ježe jemu něs[tь] vъ oblasti

ot svojeja oblasti

vo druguju oblastb

sborb po oblasti

ne idetb vb oblastb

oblastbnyi svbršenyi sborb

ostaviti svojeja oblasti

neprijati oblastbju

vo drugyja oblasti

oblastbnych je jep[i]s[ko]pz

starěišago grada oblasti toja ep [i]

$s[\mathrm{ko}] p a$

ot sbnbma oblastbnago

sb mitropolitomb toja oblasti

ot vsěchb oblastbnych[ъ] jep[i]

$s[\mathrm{ko}] p \mathrm{~b}$

oblastbnych je jep[i]s[ko]pz

jep $[\mathrm{i}] s[\mathrm{ko}] p$ b izb inoja oblasti chodit' do cirkvi iného okrsku Nk I, 262

do iných okrskov

$\mathrm{Nk}$ I, 263

o diecézach

Nk I, 263

cirkevná správa

Nk V, 270

svetské úrady

Nk XIV, 280

$\mathrm{v}$ provincii

Nk XLIX, 261

v každej provincii

Nk XLIX, 356

v každej eparchii

Nk XLIX, 358

uchvátit' eparchiu iného

Nk I, 246

$\mathrm{V}$ provincii

Nk VII, 247

v každej eparchii

Nk I, 263

eparchiálny snem

Nk I, 263

v ich okrsku

Nk II, 264

jednu eparchiu

Nk II, 265

v jednej eparchii

Nk II, 265

mimo svoju diecézu

Nk III, 265

$\mathrm{v}$ jeho právomoci

Nk III, 265

ktoré nie sú v jeho moci

Nk III, 266

zo svojej eparchie

Nk III, 266

do inej eparchie

Nk III, 266

snem tej eparchie

Nk X, 275

nejde do svojej diecézy

Nk X, 275

vrchný eparchiálny snem

Nk X, 276

opustit' svoju diecézu

Nk XII, 278

neprijatí diecézou

Nk XII, 278

do inej diecézy

Nk XII, 279

diecézneho biskupa

Nk XIII, 279

biskupa diecézy hlavného hra- Nk, XIII, 280

du

od eparchiálneho snemu

Nk XV, 283

s metropolitom tejto provincie $\mathrm{Nk} \mathrm{XV,} 283$

od všetkých eparchiálnych Nk XVI, 285

biskupov

eparchiálnych biskupov

Nk XVI, 285,

biskup z inej diecézy 


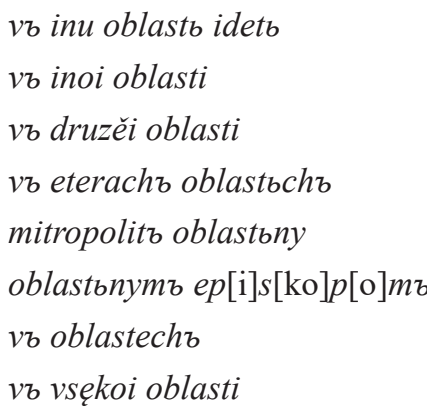

$v$ inu oblastb idetb

do inej diecézy odíde

$\mathrm{v}$ inej diecéze

$\mathrm{v}$ inej diecéze

v niektorých eparchiách

provinčný metropolita

eparchiálnym biskupom

v eparchiách

vo všetkých diecézach
Nk XX, 291

Nk XX, 291

Nk XX, 292

Nk XXVI, 301

Nk XXXVII, 324

Nk XXXVII 324

Nk XLIX, 357

Nk L, 359

Starosloviensky termín oblastb ${ }^{9}$ bol v texte Nomokánona používaný prevažne $\mathrm{s}$ významom slovenského termínu eparchia/diecéza, ${ }^{10}$ sekundárne s významom oblast', okrsok/kraj. ${ }^{11}$ Jazykovedná literatúra staroslovienskemu oblastb dáva význam moc, vláda, kraj, územie. ${ }^{12}$ Staroslovienskemu oblastb v nám prístupných slovníkoch neboli uvedené špecifické významy cirkevného práva (eparchia/diecéza) obsiahnuté v Nomokánone. Môže to súvisiet' s tým, že pôvodný význam tohto slova bol všeobecnejší (oblast', okrsok/kraj) a až neskoršie používanie v Nomokánone mu pridalo aj špecifický cirkevno-právny význam (eparchia/diecéza).

V tejto súvislosti je zaujímavé, že Slovník cirkevnej slovančiny pri slove oblastb vôbec neuvádza primárny význam tohto slova pri jeho použití v Nomoká-

9 Termín oblastb bol použitý aj v ZS v čl. 8 (s významom oblast') a v Ustanoveniach v čl. 1 (s významom /správna/ oblast'). Porovnaj Zakonъ sudnyi ljudımъ 8, ref. 8, s. 185. Zapovědi svętyichъ оtьсь 1 , ref. 8, s. 138 .

10 Termín „diecéza“ v dnešnom zmysle slova sa datuje od snemov v Kartágu (r. 390 a r. 397), zovšeobecnelo na Západe. Východ si ponechal výraz „eparchia“. TOMKO, Jozef. Zriadenie Spišskej, Banskobystrickej a Rožňavskej diecézy a královské patronátne práva v Uhorsku. Spišské Podhradie: Kňazský seminár biskupa J. Vojtaššáka Spišská kapitula, 1995, s. 53. ISBN 807142023; JAKUBČOVÁ, Renáta. Vznik a vývoj slovenských cirkevných provincií. Banská Bystrica: Právnická fakulta UMB, 2013, s. 13. ISBN 9788055705477.

11 Slovenské slovo okrsok/kraj uvádzame v takejto forme (s lomítkom / medzi nimi), pretože $\mathrm{v}$ danom období sa medzi takto označenými jednotkami nerozlišovalo. Uvedené odôvodňujeme rovnakou sémantickou motiváciou oboch slov: slovo okres má motiváciu vo význame „okresat““, kraj má motiváciu vo význame „krájat““ - obe slová majú teda identickú motiváciu, krájat', kresat' - vo význame odčleňovat' niečo od niečoho. Okres/kraj bolo označenie pre jednotku oddelenú od ostatného teritória. Uvedenému sa venujeme bližšie v nasledujúcom texte.

12 Staroslovienske oblastb je odvodzované od praslovanského *ob-volstb, zloženého z predpony *ob- a koreňa *volstb - vlast', s pôvodným významom ovládané územie. KRÁLIK, Lubor. Stručný etymologický slovník slovenčiny. Bratislava: Veda, 2016, s. 394. ISBN 9788022414937; REJZEK, Jiří. Český etymologický slovnik. Praha: Leda, 2015, s. 462. ISBN 9788073353933. 
none, teda eparchia/diecéza. ${ }^{13}$ Absencia významu eparchia/diecéza v Slovníku akiste súvisí s tým, že reflektuje najmä neskoršiu formu staroslovienčiny ako z 9. storočia, ked' sa už bežnejšie používalo slovo eparchia, ktoré má v tomto vývojovom období prevažne cirkevno-právny význam, a teda pôvodnému slovanskému slovu oblastb v neskoršom období bol ponechaný už len jeho pôvodný všeobecný význam označenia územnej jednotky. ${ }^{14}$ Môžeme teda konštatovat', že slovu oblastb sa dával jeho špecifický cirkevno-právny význam najmä v období prekladu Nomokánona, teda počas činnosti byzantskej misie.

Starosloviensky termín strojenije ${ }^{15}$ má v Nomokánone jednoznačnejší význam. ${ }^{16} \mathrm{~V}$ prevažnej časti svojho používania má význam ohraničenia eparchie/ diecézy, len v menšej miere aj význam označovania samotnej eparchie/diecézy či jej spravovania. ${ }^{17}$

13 ĎYAČENKO, Gregorij. Polnyi cerkovno-slavyansky slovar. Moskva: Vydavatel'ské oddelenie Moskovského patriarchátu, 1993, s. 364.

14 Tamže, s. 175.

15 Staroslovienske slovo strojenije má svoj etymologický pôvod v slove stroi, s významom poriadok, zriadenie. Jeho koreň je odvodený od praslovanského *strojb s nie celkom zrejmým významom. Pozri bližšie: JANYŠKOVÁ, Ilona a kol. Etymologický slovník jazyka staroslověnského. Diel 15. Praha: Tribun EU, 2010, s. 891. ISBN 9788073991982.

16 Slovo strojenije bolo použité celkovo 8-krát a jeho význam bol jednoznačný. Porovnaj Nomokanonъ 1, 3, 5, 14. In MMFH IV, s. 246, 262-263, 271, 280.

17 Editori MMFH IV uvádzajú, že termín diecéza (oblastb, strojenije) sa niekedy použil aj vo význame správnej jednotky v zmysle civilnom. Konkrétne sa jedná o použitie v I. titule, ktorý začína ,, Syntagma L titulorumI tit(b)l(ъ) a. O ustavleněi patriarchom(ъ) kanon'stěi česti. Ot sbora kostęntine grad(a) kan(onz) v. Čress strojenije jep(i)s(ko)p(o)ms ne dostoitb / choditi vъ c(b)rk(ъ)vi inogo preděla ni razměšati c(b)rk(ъ)vb, nъ po kanonomъ alıksanъdrbskomu ubo ep(i)s(ko)pu jejuptęny tъkmo stroiti, a vbstočnymъ ep(i)s(ko)p(o)mъ vъstokъ tъkmo stroiti, chranimoms nikeiskychъ kanonъ ustavomъ antiochiistěi c(b)rk(ъ)vi. Asiiskago preděla jep(i)s(ko)p(o)mъ asiiskaja tъkmo stroiti, a ponbtbskymъ ponbtbskaja tъkmo, a fręžbskymъ fręžbskaja tъkmo. Nezvanomъ že ep(i)s(ko)p(o)mъ o strojenii ne prichoditi na s(vę)št(e)nija li na ina strojenija etera c(b)rk(b)vbnaja. Chranimu že o strojeniich napisanomu kanonu, (bl(a)gojavějestb) jako vo vcękon oblasti oblastbnyi sborb da ustroitb po nikeiskomu ustavu suštaja že vъ varvarbskychъ (vъ) jazycěchъ B(ož)ija c(b)rk(ъ)vi stroiti dostoit(b) po prějatomu o(tb)čbsku obyčaju. “

Editori MMFH IV poukazujú na administratívne členenie Rímskej ríše za Konštantína Vel'kého, ked' celá ríša bola rozdelená na štyri prefektúry a prefektúry na diecézy. Podl’a tohto členenia analogicky vzniklo aj cirkevné rozdelenie na patriarcháty a exarcháty. Naproti tomu diecézou $\mathrm{v}$ cirkevnom zmysle sa pôvodne nazývala vel'ká cirkevná oblast', ktorá sa skladala z niekol'kých menších okrskov, tzv. eparchií. Eparchia teda pôvodne tvorila jednu čast' diecézy. S výnimkou vyššie citovaného ustanovenia, ked' slovo strojenije bolo uvedené v zmysle skôr civilnom, ostatné použitia tohto slova sa využívajú skôr vo význame cirkevno-právnom. Na základe uvedeného pre zjednodušenie možno konštatovat', že v pôvodnom administratívnom členení Rímskej ríše sa diecézy skladali z eparchií. Avšak v zmysle použití termínov diecéza a eparchia $\mathrm{v}$ preklade Nomokánonu sú tieto často používané skôr ako synonymá. Nomokanonъ 1, ref. 16, s. 262 a pozn. č. 1. 
V nám prístupných slovníkoch staroslovienčiny je význam slova strojenije uvedený takto: 1 . správa, riadenie; 2. rozhodnutie, ustanovenie; 3. správny okrsok, diecéza. ${ }^{18}$ Viac-menej identický význam dáva tomuto slovu aj Etymologický slovník staroslovienčiny. ${ }^{19}$ Avšak, podobne ako tomu bolo aj pri slove oblastb, aj pri hesle strojenije neuvádza Slovník cirkevnej slovančiny žiadny význam majúci cirkevno-právny charakter. Odôvodnenie je pravdepodobne identické, aké sme uviedli pri slove oblastb. ${ }^{20}$

Medzi termínmi slúžiacimi na označenie územných jednotiek (cirkevnej) správy Nomokánona sa nachádza aj slovo epachija (2-krát s významom provincia, 1-krát s významom eparchia). ${ }^{21}$ Pomerne zriedkavé používanie tohto slova, ako aj informácia z Etymologického slovnika staroslovienčiny, že sa jedná o cirkevnoslovanské slovo ${ }^{22}$ (teda o staroslovienske slovo používané v postvel'komoravskom období) nás vedie k záveru, že pravdepodobne pôvodný Metodov text toto slovo neobsahoval a bolo do textu vložené až pri prepisovaní textu pri jeho neskorších redakciách. ${ }^{23}$ Uvedenému môže nasvedčovat' aj naše prechádzajúce konštatovanie, že v cirkevnej slovančine sa termínu oblastb už nedával jeho vel'komoravský význam eparchia/diecéza, ale len význam všeobecného označenia územnej jednotky, a prepisovatel' sa ho v tomto prípade rozhodol konkretizovat' na exaktnejšiu podobu.

Na základe vyššie naznačeného je možné konštatovat', že s vel'kou pravdepodobnost'ou slovienčina v čase Metodovho prekladu Nomokánona disponovala slovnou zásobou obsahujúcou slová ako oblastb a strojenije, ktoré azda označovali väčšie správne jednotky (resp. vo väčšej miere sa používalo označenie oblastb na označenie väčšej správnej jednotky, a hranice a spravovanie tejto jednotky sa nazývali strojenije, $\mathrm{v}$ menšej miere sa termín strojenije používal na označenie tejto územnej jednotky). Konštatovaniu, že oblastb a strojenije označovali väššie správne jednotky, nasvedčuje aj význam termínov eparchia/ diecéza v cirkevnom práve. Cirkevná diecéza zaberala väčšie územie, totožné so štátnou diecézou Rímskej ríše. ${ }^{24}$ Predpoklad, že pojmy oblastb a strojenije označovali väčšie územia, naznačuje aj Život Metoda, v ktorom autor toh-

18 HAUPTOVÁ, Zoe et al. Slovník jazyka staroslověnského. Praha: ČSAV, 1985, s. 185. ISBN 8020002944.

19 JANYŠKOVÁ, ref. 15, s. 891.

20 Citovaný slovník uvádza význam v podobe: -oíxovouía- správa, spravovanie. ĎYAČENKO, ref. 13, s. 674.

21 Porovnaj Nomokanonъ 48-49, ref. 16, s. 356 a 358.

22 HAVLOVÁ, Eva et al. Etymologický slovník jazyka staroslověnského. Diel 3. Praha: Academia, 1992, s. 165. ISBN 8020000313.

23 MMFH IV. Leges, textus iuridici. Eds. Dagmar Bartoňková, Radoslav Večerka et al. Praha: KLP, 2013, s. 206.

24 JAKUBČOVÁ, ref. 10, s. 12. 
to hagiografického textu poukázal na to, že po príchode Metoda na Moravu (v roku 873) sa moravská oblastb , začala rozširovat' na všetky strany “ ${ }^{25} \mathrm{~V}$ tomto konkrétnom prípade teda pojem oblastь mohol zodpovedat' celej mojmírovskej doméne. V Živote Metoda je však tento pojem použitý ešte raz, a to v kapitole 9, ktorá popisuje ponosy bavorského episkopátu a král'a L’udovíta Nemca voči Metodovi: „,V našej oblasti učís. " $26 \mathrm{~V}$ tomto prípade je pojem oblastb chápaná z cirkevne-administratívneho hl'adiska, môže sa však takisto zhodovat' s územím moravskej arcidiecézy.

V čase prekladu Nomokánona ešte zrejme neexistovali špecifické termíny domáceho jazyka, ktoré by slúžili výlučne na označovanie jednotiek cirkevnej správy. Tá síce v nejakej nám bližšie neznámej forme existovala, ${ }^{27}$ no terminológia tejto cirkevnej správy zrejme vznikla až pod vplyvom činnosti Konštantína a Metoda. Tu si môžeme položit' otázku, prečo Metod neprevzal v plnej miere grécke (azda s výnimkou okrajového slova eparchija) či latinské termíny? Mohlo to byt' spôsobené tým, že mojmírovská miestna správa mala svoje vlastné správne jednotky, ktoré nemali priamu paralelu v byzantskom či rímskom správnom systéme a používanie ich označenia by bolo domácemu obyvatel'stvu cudzie a nezrozumitel'né.

V jazykovednej literatúre je možné sa stretnút' s názorom, že neprevzatie pôvodných gréckych (či latinských) termínov môže odhal'ovat' priamy zámer prekladatel'a: Metod ako prekladatel' Nomokánona uprednostnil zrozumitel'nost' termínov v ňom obsiahnutých pre jeho adresátov, a preto uprednostnil skôr slová existujúce $\mathrm{v}$ domácom jazykovom prostredí. ${ }^{28}$ Tým síce skomplikoval úlohu pre naše súčasné porozumenie textu, no nepochybne bol jeho preklad prijatel'nejší pre jeho vtedajších adresátov.

25 Žitije Mefodija 10, ref. 1, s. 154.

26 Žitije Mefodija 9, ref. 1, s. 151.

27 MARSINA, Richard. Vývoj cirkevnej organizácie na Slovensku v staršom stredoveku. In Vývoj cirkevnej správy na Slovensku. Eds. Vladimír Rábik et al. Krakov: Spolok Slovákov v Pol'sku, 2010, s. 15-21. ISBN 9788374903479; MARSINA, Richard. Metodov boj. Bratislava: Spolok slovenských spisovatel'ov, 2012, s. 36. ISBN 9788080616472; STEINHÜBEL, Ján. Krest’anstvo na Vel'kej Morave pred príchodom Konštantína a Metoda. In MARTÍNEK, Peter - NOGOVÁ, Mária - HUBAČ, Marián (eds.). Vzdelávanie - súčast' misie svätých Cyrila a Metoda. Bratislava: Metodicko-pedagogické centrum, 2014, s. 6-17. ISBN 9788080526108; STEINHÜBEL, Ján. Krest’anstvo medzi Vel'kou Moravou a Uhorskom. Otázka kontinuity a diskontinuity. In Historia Slavorum Occidentis, 2014, roč. 6, č. 1, s. 42-61. ISSN 2084-1213; DVORNÍK, František. Byzantské misie u Slovanů. Praha: Vyšehrad, 1970, s. 172-173.

28 Pozri bližšie MMFH IV, ref. 23, s. 206-207; VAŠICA, Josef. Literární památky epochy velkomoravské. Praha: Lidová demokracie, 1966, s. 64-65. 


\section{Termíny strana, predělb}

Výraz

$v b$ vesech(b) $i$ stranach

podb nimi sutb strany

$v b$ vsbchs $i$ stranachs

obě straně chotęštaja sę prěti

nijedinogo ot stranbnychb jep [i] $s[\mathrm{ko}] p \mathrm{~s}$

stranınymъ klirikomb
vъ vsękomb gradě $i$ straně

prebyvъšimъ vъ stranach

ne dostoitı ims preděla vъschyštati inomu

kromě preděla svojego

ne dostoitb choditi vb $c[\mathrm{~b}] r k[\mathrm{~b}]$ vi inogo preděla

asiiskago preděla jep $[\mathrm{i}] s[\mathrm{ko}] p[\mathrm{o}] m ъ$ asiiskaja tzkmo stroiti

\section{Význam}

v osadách a na vidiekoch

podliehajú im kraje

v osadách a na vidiekoch

obe strany chcejúce sa súdit'

nikoho z cudzích biskupov

cudzím klerikom

v ktoromkol'vek hrade a kraji

zostali vo svojich krajoch
Použitie

Nk VII, 248

Nk II, 264

Nk VII, 272

$\mathrm{Nk} \mathrm{XV}, 28$

Nk XX, 292

Nk XX, 292

Nk XXXIII, 313

$\mathrm{Nk}$ XXXVII, 324

nepatrí sa im zabrat' územie Nk II, 246 pridelené inému

okrem svojho údelu Nk III, 246

nepatrí sa vchádzat' do ko- Nk I, 262

stolov iného okrsku

biskupom ázijskej diecézy $\mathrm{Nk} \mathrm{I,} 262$

len ázijské veci spravovat'

Staroslovienske slovo strana sa opakovane vyskytovalo v texte Nomokánona s významom kraj, kraje (v zmysle územnej jednotky) ${ }^{29}$ vidiek, ale aj strana súdneho sporu. Nachádzame ho však aj v Pochvalnom slove o Cyrilovi a Metodovi, ktorého autor popisujúc príchod Metoda na Moravu napísal, že prišiel vъ strany moravbsky, ${ }^{30}$ čo by sme v tomto prípade mohli vol’ne preložit' ako „moravské končiny“. Ked' sa Morava po príchode arcibiskupa Metoda „,začala rozširovat' na všetky strany ", 31 autor mal akiste na mysli končiny, smery.

Podobný význam si ponechalo slovo strana dodnes v bulharčine, macedónčine, starej češtine, ukrajinčine či ruštine. ${ }^{32}$ Staroslovienske strana bolo v texte

29 Často išlo o označenie Moravy ako celej krajiny. Porovnaj LYSÝ, Miroslav. Moravania, Mojmírovci a Franská ríša. Štúdie $k$ etnogenéze, politickým inštitúciám a ústavnému zriadeniu na územi Slovenska vo včasnom stredoveku. Bratislava: Atticum, 2014, s. 107. ISBN 9788097138141; HUDÁČEK, Pavol. Královstvo, monarchia alebo štát ? (k otázke používania konceptu štátu v ranom stredoveku). In Forum historiae, 2014, roč. 8 , č. 2, s. 1-44. ISSN 1337-6861.

30 Pochvalnoje slovo Kirillu i Mefodiju. In MMFH II, s. 173.

31 Ref. 1.

32 JANYŠKOVÁ, ref. 15, s. 887. 
Nomokánona dvakrát použité aj s významom vidiek. Avšak v širšom kontexte týchto dvoch ustanovení môžeme význam vidiek nahradit' významom „to čo je bokom, to čo je stranou“. Na tomto mieste je zrejmé, že sémantická motivácia slova strana, kraj, dokonca aj slova okres je rovnaká: vyčlenenie jednotky jej oddelením od ostatného územia: okresaním (okres), ${ }^{33}$ okrajom/krájaním (kraj) ${ }^{34}$ či stranou (stsl. strana), alebo medzou, teda vymedzením územia (výraz medza prešiel do staromad'arského jazyka vo forme megye). ${ }^{35}$

Vyššie uvedený význam staroslovienskeho strana vo význame vidiek/to čo je bokom, čo je stranou, je etymologicky správny. Aj v dnešnom jazyku sa slovo vidiek používa skôr na označenie toho „,̌o je mimo mesto, mimo centrum“. A práve takýto význam by sme skôr pridelili vyššie uvedeným dvom použitiam slova strana, než význam súčasného „vidiek“. Vyššie uvedené textové ukážky poukazujú, že odvodeniny staroslovienskeho strana $\mathrm{v}$ podobe stranbnychr,${ }^{36}$ stranınymъ boli používané vo význame cudzí. Nie je to prekvapivé, nakol'ko tento význam sa nám zachoval $v$ archaickej slovenčine, ${ }^{37}$ ako aj v súčasných východoslovanských jazykoch. V XV. titule Nomokánona sa zachovalo jedno použitie slova strana vo význame sporovej strany. Význam tohto použitia je takmer identický s označením sporových „strán“ v súčasnej slovenčine. ${ }^{38}$

Takmer všetky významy, ktoré sme pri slove strana uvideli pri jeho použití v Nomokánone, existovali aj v archaickej slovenčine. Historický slovník slovenského jazyka uvádza pri slove strana takéto významy: priestor, oblast', kraj, končiny, územie, bok, bočná plocha, sporová strana. ${ }^{39}$ Ked’že sa jednalo o slovo, ktorého hlásková forma, ale aj význam boli takmer identické v staroslovienčine aj v archaickej slovenčine, je možné predpokladat', že toto slovo existovalo v tejto forme a s týmto významom aj v slovienčine. Nie je totiž možné predpokladat', že ak by toto slovo doniesli do nášho jazykového prostredia členovia byzantskej misie, za jej relatívne krátkeho pôsobenia by sa v domácom jazyku uchytilo tak,

33 KRÁLIK, ref. 12, s. 400; REJZEK, ref. 12, s. 469.

34 REJZEK, ref. 12 s. 341; KRÁLIK, ref. 12, s. 297.

35 Pozri bližšie: ONDRUŠ, Šimon. Odtajnené trezory slov. II. Martin: Matica Slovenská, 2002, s. 27. ISBN 8070906596.

36 V uvedenej podobe používa predmetný termín aj Súdny zákon pre l’ud: „Iže od stranbnъch kupits plénьnika... " Kto od cudzincov kúpi zajatca... Pozri bližšie: Zakonъ sudnyi ljudımъ 19, ref. 8, s. 167. Preklad v MMFH má slovné spojenie „od cudzích vojakov“, zatial’ čo starosloviensky text slovo „vojakov“" neobsahuje.

37 MAJTÁN, Milan (ed.). Historický slovník slovenského jazyka V. Bratislava: Slovenská akadémia vied, 2000, s. 497. ISBN 8022406287.

38 O tom, že slovo strana sa používalo aj v archaickej slovenčine s významom označenia sporovej strany máme mnoho písomných svedectiev. Porovnaj KUCHAR, Rudolf. Právo a slovenčina v dejinách. Budmerice: Rak, 1998, s. 26, 85, 99, 101, 103, 104. ISBN 8085501147.

39 MAJTÁN, ref. 37, s. 497. 
aby aj v nasledujúcich storočiach bolo používané v identickom význame. Je to teda o termín, pri ktorom Metod opätovne reflektoval tradíciu jeho používania v moravskom prostredí.

Môžeme konštatovat', že staroslovienske slovo strana bolo už v období prekladu Nomokánonu viacvýznamové, ale aj napriek tomu pri jeho čítaní nie je problém z kontextu celého ustanovenia pochopit', v akom význame bolo slovo použité. Avšak priradit' termín strana konkrétnej územnej jednotke miestnej správy je problematické. Na základe dobového používania staroslovienskeho strana, ale aj archaického slovenského strana s významom vidiek, to čo je bokom/stranou, môžeme sa len pokúsit' konštatovat', že týmto termínom sa pravdepodobne označovali územia ležiace mimo centier (ktorými boli hrady).

Pre poznanie pomenovania jednotlivých územných správnych jednotiek na Morave je dôležitým staroslovienskym termínom predělb. Pri letmom náhl'ade na toto slovo by sme ho mohli identifikovat' so slovenským termínom údel, ktorého existencia sa niekedy predpokladá už v mojmírovskom (a neskôr arpádovskom) období ako územie pridel'ované mladším členom mojmírovského kniežacieho rodu. Samotný termín údel však v 9. storočí známy nebol a jedná sa o neologizmus. ${ }^{40} \mathrm{~V}$ Nomokánone má predělb širší význam. Použité bolo štyrikrát, a to vo význame územie, údel, okrsok, diecéza. Hoci sa v prípade druhej textovej ukážky použiva termín predělb s významom údel, nie je možné nájst' priamy súvis s inštitúciou ,nitrianskeho údelu“. V tomto prípade Nomokánon používal termín predělı s významom všeobecne určenej územnej jednotky, ktorá je biskupovi pridelená (udelená) k spravovaniu a biskup nemá vykonávat' svoje právomoci mimo túto územnú jednotku.

Sémantická motivácia takto použitého termínu preděl je vel'mi blízka motivácii vzniku a používania termínu údel, ako ho poznáme dnes (niečo čo je niekomu pridelené, udelené). Starosloviensky predělı (hranica, medza, územie, končiny, kraj) je odvodený od stsl. dělb s významom diel, čast'. ${ }^{41}$ Vznik a používanie slova predělb od slova dělb s významom diel, čast', poukazuje na rovnakú motiváciu ako súčasné slovenské slová používané na označovanie územných jednotiek kraj, okres s vyššie naznačenou motiváciou krájat', kresat', teda odčleňovat' niečo od niečoho. Predělı bol teda územnou jednotkou odčlenenou od ostatného územia.

$40 \mathrm{~K}$ prieniku termínu údel do historiografickej terminológie porovnaj WIHODA, Martin. Morava v době knižeci 906-1197. Praha: Nakladatelství Lidových novin, 2010, s. 9-10. ISBN 9788071065630.

41 HAVLOVÁ, ref. 22, s. 129. Ján Steinhübel uvádza, že do roku 1043 bol hranicu Uhorska hrebeň Fischbašských Álp zvaných mons Predel, oddel'ujúci povodie strednej Mury s Korutánskom. STEINHÜBEL, ref. 7, s. 169. 


\section{Termíny gradb, město, vbsb}

Doterajšie termíny vyjadrovali väčšie územia, v tejto časti štúdie sa preto pozrieme na označenia sídel.

\begin{tabular}{|c|c|c|}
\hline Výraz & Význam & Použitie \\
\hline vъ vsękomb gradě $i$ straně & $\begin{array}{l}\text { v ktoromkol'vek hrade alebo } \\
\text { kraji }\end{array}$ & Nk, XXXIII, 313 \\
\hline vъ Kostęntině grad [ě] $]$ & v Konštantínopole & Nk Index, 245 \\
\hline ne prijemleměchs gradom & nie sú prijatí hradom & Nk X, 249 \\
\hline ostavlęti města svojego i grada & opustit' svoje miesto a hrad & Nk XII, 249 \\
\hline 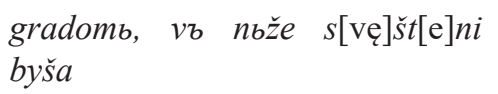 & $\begin{array}{l}\text { hradom, pre ktorý boli ordi- } \\
\text { novaní }\end{array}$ & Nk XII, 249 \\
\hline ot grada vъ grad prechoditi & prechádzat' z hradu do hradu & Nk XII, 249 \\
\hline $\begin{array}{l}\text { ni dvoju gradu cbrkъvamъ klirika } \\
\text { iskati }\end{array}$ & $\begin{array}{l}\text { ani chrámom dvoch hradov } \\
\text { uchádzat' sa o klerika }\end{array}$ & Nk XIX, 252 \\
\hline vъ druzěchъ graděchъ & $\mathrm{v}$ iných hradoch & Nk XX, 252 \\
\hline a jelikože uže gradı & a ak už hrad & Nk II, 265 \\
\hline vъ graděchъ $i v ъ$ vsbch & v hradoch a osadách (vsích) & Nk II, 265 \\
\hline $\operatorname{grad}[\mathbf{b}]$ ili města ta & tie hrady alebo miesta & Nk III, 266 \\
\hline vъ čjužemb gradě & v cudzom hrade & Nk III, 266 \\
\hline ep $[\mathrm{i}] s[\mathrm{ko}]$ pa gradbskago & hradského biskupa & Nk VII, 273 \\
\hline pričbtb grad $[\mathrm{a}] \operatorname{togo}$ & klérus toho hradu & Nk X, 275 \\
\hline svojego grada ostaviti & opustit' svoj hrad & Nk XII, 278 \\
\hline ot grada $v b$ gradb & $\mathrm{z}$ hradu do hradu & Nk XII, 279 \\
\hline starěišago grada oblasti & hlavného hradu oblasti & Nk XIII, 280 \\
\hline $\begin{array}{l}\text { predb stolbnika } \\
\text { juščago grad }[\mathrm{a}] \text { ] }] \text { [a]rbstvu- }\end{array}$ & $\begin{array}{l}\text { pred metropolitu cisárskeho } \\
\text { hradu }\end{array}$ & Nk XV, 284 \\
\hline vъ inъ grad [ъ] prijatb budetb & $\mathrm{v}$ inom hrade bude prijatý & Nk XVIII, 287 \\
\hline ne dostoitb klirikomъ $v ъ$ v gradu & $\begin{array}{l}\text { nie je dovolené klerikom } \\
\text { v hrade }\end{array}$ & Nk XIX, 290 \\
\hline$v b c[\mathrm{~b}] r k[\mathrm{~b}] v b$ inogo grada & do kostola iného hradu & Nk XIX, 291 \\
\hline$v c[\check{\mathrm{e}}] s[\mathrm{a}] r b s t v u j u s ̌ c ̌ i i ~ g r a d[\mathrm{~b}]$ & do cisárskeho hradu & Nk XX, 291 \\
\hline da otidutb iz grada & nech odídu z hradu & Nk XX, 291 \\
\hline vъ jeterěchъ městěchъ i graděch & $\begin{array}{l}\text { v niektorých miestach a hra- } \\
\text { doch }\end{array}$ & Nk XXV, 295 \\
\hline $\begin{array}{l}\text { cbrkbvbnyja i gradbskyja mętutb } \\
\text { eešti }\end{array}$ & mätú veci cirkevné a svetské & Nk XXXIII, 313 \\
\hline
\end{tabular}


chodęšče veščinu vъ graděchъ bez volě gradbskago ep $[\mathrm{i}] s[\mathrm{ko}] p a$ suščimb vo vsękomb gradě $i$ straně

gradbskymb ep $[\mathrm{i}] s[\mathrm{ko}] p[\mathrm{o}] m b$

$E p[\mathrm{i}] s[\mathrm{ko}] p u$ že gradbskomu

vъ vsbch , ili vъ graděch

da ne vъ gradě $d v a$ ep $[\mathrm{i}] s[\mathrm{ko}] p a$ budeta

vъ kojembždo gradě

ktoryi ljudinъ vъ gradě živyi

ostavlęti města svojego i grada

ne ostavlęti že městr

$\operatorname{grad}[]$iliměstata

ne dostoitb vъ čjužems gradě cho-

diti ni vъ město, ježe jemu něstb $v \mathrm{v}$ oblasti

$v ъ$ mëstěch chb ep [i] $][\mathrm{ko}] p \mathrm{~s}$

sъ voleju ep[i]s[ko]pa města togo

ni otvětu města iměti.

ostavlb svoje město

da na svoja města koždo idetb.

$v ъ$ jeterěch

ne dostoitb slugamъ města iměti vo dijakonbstvě

vъ nichъže městěchъ postrigli sę sutb

městostavnomu jep(i)s(ko)pu

město li vbsbskago ep[i]s[ko]pa li prozvjutera chodiac neporiadne po hra- Nk XXXIII, 313 doch

bez povolenia hradského bis- Nk XXXIII, 313 kupa

nachádzajúci sa v akom- Nk XXXIII, 313 kol'vek hrade či kraji

hradským biskupom Nk XXXIII, 314

hradskému biskupovi Nk XXXIII, 314

$\mathrm{v}$ osadách alebo $\mathrm{v}$ hradoch $\quad$ Nk XXXVIII, 329

nech nebudú $\mathrm{v}$ hrade dvaja Nk XXXVIII, 329 biskupi

v každom hrade

Nk XXXVIII, 330

laik, ktorý žije v hrade

Nk XLVII, 352

opustit' svoje miesto a hrad Nk XII, 249

neopúšt'at' miesta

Nk XXXIII, 257

hrad alebo tie miesta

Nk III, 266

nepatrí sa do cudzieho hradu Nk III, 266

chodit' ani na miesto, ktoré

nie je $\mathrm{v}$ jeho oblasti

v miestach ovládaných inými Nk III, 266

biskupmi

s dovolením biskupa toho Nk III, 266 miesta

ani obhájenie miesta (postu) Nk XVII, 286 mat'.

opustí svoje miesto (post/ Nk XX, 291 úrad)

nech sa každý vráti na svoje Nk XX, 293 miesto (post).

v niektorých miestach a hra- Nk XXIII, 295 doch

nepatrí sa sluhom mat' miesto Nk XXVI, 301

$\mathrm{v}$ diakonii

v miestach, kde boli postrih- Nk XXXIII, 313 nutí

miestnemu biskupovi Nk XXXIV, 317

miesto (post) alebo vidiecke- Nk XXXVIII, 329

ho biskupa alebo presbytera 
vъ svoich městěch

vъ graděch $i$ vъ vsbch

$v b$ vsbch $i$ stranachs

vъ vsbchъ, ili vъ graděch vo svojich miestach

v hradoch a osadách

v osadách a na vidiekoch

v osadách (vesnice) alebo Nk XXXVIII, 329 $\mathrm{v}$ hradoch
Nk XLIX, 358

Nk II, 265

Nk VII, 272

\section{Gradъ}

Staroslovienske slovo gradb sa $\mathrm{v}$ texte Nomokánona nachádzalo celkovo 41-krát. ${ }^{42} \mathrm{Z}$ tohto celkového počtu je 7-krát v slovnom spojení Kostęntina grad (Konštantínopol), teda centrum Byzantskej ríše. Ustálený význam majú aj ostatné 34 použitia slova gradb a jeho gramatické formy, napr. gradbskyij. Je zaujímavé, že pri takom pomerne častom použití tohto slova je jeho význam tak jednoznačný, bez väčších významových alternácií. Svedčí to o tom, že sa jednalo o slovo, ktorého význam bol v čase byzantskej misie ustálený, a teda dlhodobo používaný.

Zo staroslovienskeho gradz očividne pochádza súčasné slovo hrad. Pôvodným významom stsl. gradz je opevnené (ohradené) sídlisko. Predpokladáme praslovanskú podobu ${ }^{*}$ gords s rovnakým významom. ${ }^{43}$

Pôvodné hrady boli identické s plochou hradu, vymedzenou opevnením (neskôr hradbami). Až neskôr sa z rozličných dôvodov mohlo začat' rozlišovat' medzi úzko vymedzeným opevnením (hradom) a osídlením, ktoré často vznikalo $\mathrm{v}$ okolí hradu, resp. v podhradí (mestom). Aj preto pripomeňme dost' podstatnú vec, a to že ani v latinskom jazyku sa pôvodne terminologicky nerozlišovalo medzi oboma útvarmi. Historici tak stoja pred nel'ahkou úlohou rozhodnút' sa, či latinský civitas alebo stsl. gradı preložit' ako hrad, alebo ako mesto. Situáciu neul'ahčuje ani skutočnost', že pôvodné právnohistorické vymedzenie stredovekého mesta, dané udelením privilégia, bolo oslabené výskumom hospodárskych dejín, skúmajúcich okrem iného aj predprivilegiálne sídelné lokality. ${ }^{44}$ Azda nie je prekvapením, že jednotu medzi bádatel'skou obcou v tomto ohl'ade nenájdeme. Pre naše potreby je zároveň dôležité ešte upozornit', že Metod pri preklade Nomokánonu vychádzal z gréckeho výrazu $\pi 0 \lambda \imath \varsigma$, ktorý preložil staroslovien-

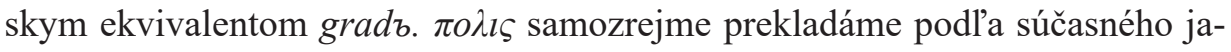
zykového úzu ako mesto, avšak Metod prekladal Nomokánon pre potreby mo-

42 Súdny zákon pre l’ud obsahuje slovo gradъ v čl.15 a v čl. 21. Porovnaj Zakonъ sudnyi ljudımъ 15 a 21 , ref. 8, s. 187, 191.

43 KRÁLIK, ref. 12, s. 207; REJZEK, ref. 12, s. 235; HAVLOVÁ, Eva et al. Etymologický slovník jazyka staroslověnského. Diel 4. Praha: ČSAV, 1994, s. 198. ISBN 8020004912.

44 Pozri bližšie aj s prehl'adom bádania a najnovšej literatúry LYSÁ, Žofia. Bratislava na ceste k privilégiu 1291. Štúdie k dejinám Bratislavy v 13. storočí. Bratislava: Historický ústav SAV, 2014, s. 13-29, 54-68. ISBN 9788089396313. 
ravskej cirkvi a pre obyvatel'ov Moravy. A práve z tohto dôvodu je namieste uprednostnit' preklad termínu gradı slovenským výrazom hrad, aby nevznikli zbytočné nedorozumenia o povahe týchto opevnených sídel. ${ }^{45}$ Zretel'a hodné tiež je, že výraz gradı použil Metod aj pri tvorbe Súdneho zákonnika pre l’ud, pri ktorom vychádzal z textu gréckej Eklogy, kde pôvodným gréckym termínom bola $\pi 0 \lambda \imath \tau \varepsilon l \alpha .{ }^{46} \mathrm{Ak}$ aj teda byzantskými (gréckymi) ekvivalentmi pôvodných termínov $\pi 0 \lambda \imath \varsigma$ a $\pi 0 \lambda \imath \tau \varepsilon l \alpha$ sú v dnešnej slovenčine mestá, ekvivalentnými sídelnými jednotkami pre 9. storočie sú hrady, ktorých funkcie, podoba, hospodárska úroveň či správa museli byt' výrazne odlišné od pomerov v Byzancii.

\section{Město}

V Nomokánone sa často použivalo i staroslovienske slovo město ${ }^{47}$ Spomedzi textových ukážok sme vypustili tie, kde slovo město bolo používané s významom „namiesto“ (jastb krovb vъ messъ město li zvěrojadinu, ${ }^{48}$ vina město olb atd’.). V zostávajúcich pätnástich výskytoch sa staroslovienske město používalo ako označenie plochy alebo s významom miesto ako úrad, post. Identické významy sú uvádzané aj slovníkoch staroslovienčiny: 1. miesto, priestor; 2. úrad, postavenie..$^{49}$ Možno konštatovat', že pri použití slova město v textoch Nomokánona je jeho význam dobre zrozumitel’ný a významovo relatívne ustálený. Jedná sa o slovo praslovanského pôvodu, s pôvodnou formou *město, s predpokladaným

45 Za takéto nedorozumenie pokladáme aj práce Ferdinanda Uličného, ktorý sa nielenže prikláňa $\mathrm{k}$ výrazu mesto aj pre útvary 9 . storočia, ale vychádza z toho, že obyvatelia týchto „miest“ boli „mešt’ania“. Tento výraz však samozrejme evokuje ustálený význam mešt’ana, ktorý bol nielen obyvatel'om mesta, ale najmä nositel'om špecifických práv (najmä práva volit' si predstavených svojej komunity a vyňatie spod právomoci župana), o ktorých však do 13. storočia nemá $\mathrm{v}$ našom priestore zmysel hovorit'. Vidiet' je to predovšetkým v Uličného monografii, ktorá konceptualizuje a hypertrofuje nami analyzované sídla z hl'adiska ich hospodárskej podstaty ako mestá a ich obyvatel'ov ako mešt'anov. ULIČNÝ, Ferdinand. Trhy a mestá na Slovensku v 9. - 12. storočí. In SEDLÁK, Vincent (ed.). Zborník príspevkov k slovenským dejinám. Kživotnému jubileu univ. prof. PhDr. Richarda Marsinu, DrSc. Bratislava: Slovenský historický ústav Matice slovenskej, 1998, s. 53-61; ULIČNÝ, Ferdinand. Nitra - mesto v 9. - 12. storočí. In MARSINA, Richard (ed.). Nitra v slovenských dejinách. Bratislava: Matica slovenská, 2002, s. 140-146; ULIČNÝ, Ferdinand. O pôvode a význame slov ves, dedina, mesto. In Historický časopis, 2010, roč. 58, č. 3, s. 575-581. ISSN 0018-2575; ULIČNÝ, Ferdinand. Dejiny Slovenska v 11. až 13. storočí. Bratislava: Veda, 2013, s. 456-475. ISBN 9788022412926; ULIČNÝ, Ferdinand. Obyčajové právo mešt’anov do 13. storočia. In Historický časopis, 2018, roč. 66, č. 2, s. 219-240. ISSN 0018-2575.

46 Zakonъ sudnyi ljudımъ 21, ref. 8, s. 191 a pozn. č. 51.

47 Súdny zákon pre l’ud obsahoval dvakrát sa opakujúce slova město v čl. 22. V oboch prípadoch bolo použité s významom „miesto“. Porovnaj Zakonъ sudnyi ljudьmъ 22, ref. 8, s. 191.

48 Nomokanonъ 29, ref. 16, s. 306.

49 ERHART, Adolf et al. Etymologický slovník jazyka staroslověnského. Diel 8. Praha: ČSAV, 1998, s. 470. ISBN 8020006974. 
pôvodným významom fyzického označenia plochy. Význam, ktorý toto slovo nadobudlo $\mathrm{v}$ neskorších slovanských jazykoch (v slovenčine mesto s významom lat. oppidum, urbs, civitas), je sekundárny. Možno teda predpokladat', že aj v slovienčine slovo město malo význam fyzického označenia miesta, následne označenia úradu či postu (nie význam mesto/oppidum/urbs).

$\mathrm{Z}$ toho vyplýva, že termín město nebol v sledovanom období používaný na označovanie konkrétnych územných jednotiek mojmírovskej miestnej správy. Ak by sme hl'adali jeho použitie v systéme miestnej správy, skôr bolo používané na abstraktné označenie úradníckeho miesta, postu. Nešlo však o označovanie konkrétneho postu identifikovatel'ného v hierarchickej štruktúre úradov, ale len na označenie úradníckeho miesta ako takého.

Stojí však určite za povšimnutie, že v Nomokánone Metod používal výraz

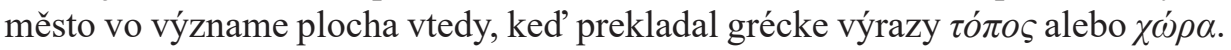
Prvé by sme do súčasnej slovenčiny preložili ako miesto, to druhé ako krajina. Pre neskorší terminologický vývoj sú podl'a nášho názoru zaujímavé tie slovné spojenia, pri ktorých sa město dostalo do protikladu s výrazom gradı. Město sa tak stalo $\mathrm{v}$ istých prípadoch protikladom gradu, napríklad ak biskup nesmel opustit' svoje město a gradb (XII, 249), alebo nemal chodit' do iného gradu ani města (III, 265). Titul III Nomokánonu (na s. 265-266) rozoberá, že biskup nemá chodit' do hradov a osád (vsь), ktoré nie sú pod jeho právomocou a mal by byt' zbavený svojej hodnosti, ak tak urobil bez dovolenia biskupa toho gradıu či města. Práve v tomto titule vidíme, že u Metoda bolo město okolím gradıu, čiže miestom, kde sa nachádzajú vsb. Preto územie, na ktorom biskup vykonával podl'a staroslovienskeho prekladu Nomokánonu svoju právomoc, sa skladalo zo sídelného gradu a jemu prináležiaceho okolia (města). Nedá sa celkom jasne vystopovat', či Metod túto sémantickú dvojicu vytvoril svojím prekladom sám, alebo sa prispôsobil domácemu jazyku. Zo štýlu jeho prekladu by sa dala predpokladat' viac druhá možnost'.

Hoci to $\mathrm{s}$ našou témou súvisí nepriamo, radi by sme upozornili ešte na jednu okolnost', ktorá súvisí s výrazom město. Je totiž evidentné, že v neskoršom období sa jeden z významov tohto slova, teda okolie hradu (vidiek hradu), stal východiskom pre vznik pojmu mesto. Žial', neskoršie staroslovienske pamiatky (pôvodom) z Čiech, najmä svätováclavské a svätol'udmilské legendy, nám nepomôžu a k dispozícii nám tak zostala len Česká veršovaná kronika zo začiatku 14. storočia. Jej po mene neznámy autor zachytil slávnu radu veštkyne Libuše o založení města Praha. ${ }^{50}$ Rozlišovanie medzi hradom a mestom je však vel’mi

50 Staročeská kronika tak řečeného Dalimila (1). Vydáni textu a veškerého textového materiálu. Eds. Jiří Daňhelka et al. Praha: Academia, 1988, s. 150. „, Stavte město, to vám káži, / tu kdežt to já vám ukáži, / u Vltavy pod Petřinem, / kdežto tesař činí práh s svým synem. / Pro práh městu vzdějte Praha, / toho města bude silná dráha. / Neb jakž kniežata i králové, / lidé silní 
pekne vyobrazené aj v rozprávaní o tzv. Luckej vojne, v ktorej sa pri zmienke o Vratislavi (Vlastislavi) spomína, že ,, to město bieše on [t. j. Vladislav, údajný žatecký knieža - R. J., M. L.] stavil / a nad ním tvrdý hrad byl postavil ". ${ }^{51}$ Naše predpoklady môžeme čiastočne potvrdit’ aj latinskými listinami. Rozdiel medzi hradom (castrum) a jeho okolím (locus) sa nám tak objavuje v listine Nitrianskej kapituly z roku 1246, potvrdzujúcej odovzdanie istého hradu a územia (cum loco) pri ňom ležiacom. ${ }^{52}$

Azda preto nebudeme d'aleko od pravdy, ak vyslovíme domnienku, že termín město získal nový význam v 13. storočí vd'aka tomu, že komunity obyvatel'ov sídliacich v okolí hradov získali od panovníkov výsady. ${ }^{53}$ Dovtedy používaný výraz město ako okolie hradu získal nový význam v podobe označenia sídelnej jednotky, na ktorej žilo privilegované spoločenstvo mešt'anov (cives) a hostí (hospites).

\section{VьSь}

Slovo vbsb je v Nomokánone pomerne zriedkavo obsiahnuté. ${ }^{54}$ Celkovo bolo $\mathrm{v}$ texte Nomokánona použité len trikrát, ale pri týchto použitiach bol jeho význam pomerne jednoznačný - osada. ${ }^{55}$ (V archaickej slovenčine bol bežne používaný termín ves ${ }^{56}$ tento termín sa zachoval aj v súčasnej češtine. V súčasnej

jako lvové / proti prahu kláněji hlavu, / aby ji jměli zdrávu, / takež proti Prazě, městu mému; / nebo bude čest i chvála jemu. "

51 Staročeská kronika tak řečeného Dalimila, ref. 50, s. 251. Mohli by sme pri citovaní tohto textu spomenút', že jeho predlohou bola kronika pražského kanonika Kosmasa, ktorý túto pevnost' nazýva iba hradom (urbs). Cosmae Pragensis Chronica Boemorum I 10. Monumenta germaniae historica, Scriptores rerum Germanicarum Nova series. Ed. Bertold Bretholz. Berolini: Weidmanos, 1923, s. 26.

52 Codex diplomaticus et epistolaris Slovaciae II (d'alej CDES II). Ed. Richard Marsina. Bratislavae: Vydavatel'stvo SAV, 1987, č. 238, s. 165: ,cum uno loco castri eidem castro adiacentem... “ Roku 1251 daroval uhorský král’ Belo IV. „, locum sub castro Turul“ premonštrátskemu rádu. Porovnaj tamže, č. 370, s. 256-257.

53 Nemuseli však byt’ len v blízkom okolí hradov, ako dosvedčujú výsady pre Trnavčanov v Bratislavskom komitáte ,,in (...) locus, qui Zumbothel dicitur“. CDES II, ref. 52, č. 44, s. 30.

54 Slovo vsi sa vyskytuje jedenkrát aj v Súdnom zákone pre l’ud v čl. 15, s významom českého „ves“. V článkoch 1 a 15 sa používa obsahom podobné selo. Porovnaj Zakonъ sudnyi ljudbmъ 1 a 15 , ref. 8 , s. 178 a 187.

55 Slovník jazyka staroslověnského cituje aj vyššie uvedené použitia slova vbsb v Nomokánone a dáva im význam českého ,ves“, „vesnice“. KURZ, Josef et al. Slovník jazyka staroslověnského. Diel 6. Praha: Nakladatelství Československé akademie věd, 1958, s. 368. ISBN 8020002944.

56 Práve v staroslovienskom slove vbsь a českom a slovenskom slove ves je zretel’ne postrehnutel’ná posledná zmena, ktorá stála za úplným rozpadom praslovanskej jazykovej jednoty (tá sa kladie približne do 10. st.) - jedná sa o zánik a vokalizáciu jerov. V slove vbsь na základe Havlíkovho pravidla zanikol posledný jer a druhý sa vokalizoval na písmeno „e“. K Havlí- 
slovenčine nachádzame slovo ves už zriedkavejšie, skôr sa nám zachovalo najmä v miestnych označeniach miest typu Spišská Nová Ves, Pavlova Ves atd'.). ${ }^{57}$ Slovník jazyka staroslověnského uvádza heslo vbsь dvakrát. V prvom prípade je slovu vbsь pripísaný vyššie uvedený význam osada, pri druhom použití je tomuto heslu (foneticky identickému vьsь) daný význam „všeobecný“, „každý, „celý“. Práve koreňom slovenského slova „všeobecný“ je slovo obec, teda jedno zo synonymov archaickejšieho slova ves. Sémantická motivácia slov vbsь a obec je teda rovnaká.

Ked’že termín vbsь sa zriedkavo vyskytoval v Nomokánone, nie je možné len na základe rozboru textu Nomokánona konštatovat', že sa jednalo o termín ustálený a dlhodobo používaný v jazykovom prostredí mojmírovskej Moravy. ${ }^{58}$

Ustálenost' a dlhodobost' jeho používania možno však predpokladat' na základe etymologického rozboru: základom staroslovienskeho vbsb je praslovanské *vbsb. Hoci pritom tieto slová majú identickú podobu, ich význam identický nemusí byt'. Praslovanské *vbsb malo predpokladaný význam sídliska príslušníkov rodu/rodiny. Staroslovienske vısь sa však prekladá vo význame osada, bez bližšieho poukázania, či v tejto osade žili príslušníci jedného rodu/rodiny. Avšak vzhl'adom na poznatky o rodinnom živote a rodinoprávnych vzt'ahoch na Vel'kej Morave je možné predpokladat', že aj staroslovienskemu vbsb v období Vel'kej Moravy bol stále priznávaný význam označenia miesta, kde žijú príslušníci rodiny/rodu či rodinného nedielu. ${ }^{59}$

kovmu pravidlu zániku a vokalizácii jerov pozri bližšie PUKANEC, Martin. Od indoeurópčiny k praslovančine. Brno: Tribun EU, 2010, s. 51. ISBN 9788073992323.

57 K problematike používania a významu slov ves a dedina pozri bližšie: ŽIGO, Pavol. Dedina ves - selo - derevňa v nárečiach starých Slovanov. In Historický časopis, 2009, roč. 57, č. 2 , s. 329-338. ISSN 0018-2575; ŽIGO, Pavol. O pôvode a význame slov ves a dedina. In Historický časopis, 2011, roč. 59, č. 1, s. 119-125. ISSN 0018-2575; Tiež STANISLAV, Ján. Odkryté mená slovenských miest a dedin. Martin: Matica Slovenská, 2008. ISBN 9788070908891.

58 Existoval však výraz „všetci Moravania“, ktorý nachádzame v príslušných jazykových ekvivalentoch nielen v latinsky písaných prameňoch, ale aj v Živote Metoda. Svätopluk vítal Metoda „sb vbsbmi moravljany“. Ref. 1.

59 Pozri bližšie: JÁGER, Róbert. Lingvisticko-etymologická analýza najstarších termínov rodinnoprávnych vzt’ahov v západo-slovanskom jazykovom prostredí. In Štát a právo, 2016, roč. 2, č. 1, s. 88-129. ISSN 1339-7753; GÁBRIŠ, Tomáš - JÁGER, Róbert. Najstaršie právo na Slovensku? Pokus o rekonštrukciu predcyrilometodského normativneho systému. Bratislava: Wolters Kluwer, 2016, s. 171 a inde. ISBN 9788081685071; ŽIGO, Pavol Tendencie v pomenovaní rodinných vzt'ahov v slovenčine. In Dialog pokoleń w języku potocznym, w języku wsi i miasta, $w$ literaturze, w publicystyce, w tekstach kultury. Warszawa: Towarystwo kultury języka, 2015, s. 331-342. ISBN 9788364111099; ŽIGO, Pavol. Pomenovania príslušníkov rodiny a rodinných vzt’ahov v predspisovnej slovenčine. In Forum historiae, 2012, roč. 6, č. 1. ISSN 1337-6861.

Proti hypotéze, že vo vel'komoravskom období vo vbsi prevládali vzt'ahy primárne rodinné je možné oponovat' dobovými miestnymi názvami väčšiny osád. Ján Stanislav poukazuje na 
Na rozdiel od vyššie uvedených slovných označení jednotlivých územných jednotiek, pri termíne vbsь máme istotu, že je to najmenšia sídelná jednotka, ktorú obývali príslušníci rodiny/rodu, teda rodinného nedielu. Pre bližší popis riadenia tejto jednotky môžeme použit' kombináciu poznatkov rodinnoprávnych vzt’ahov v rodinnom nediele s poznatkami lingvistickej etymológie analyzujúcej postavenie hlavy rodiny, ktorá stála na čele rodinného nedielu, kryjúceho sa s územím vbsi.

Štefan Luby uvádza, že na čele rodu (rodinného nedielu či čel’ade) stál otec rodiny. Otcom rodiny nebol len otec detí, ale najstarší žijúci mužský predok (otcovský nediel) alebo iný najstarší mužský člen rodu (bratský nediel). Bol to starešina, děd (praotec, starý otec) alebo starosta.$^{60}$ Práve termín starešina máme, na rozdiel od starostu, dochovaný aj v texte Nomokánona. Slovo starosta sa nevyskytuje v Nomokánone ani v iných staroslovienskych pamiatkach. Šimon Ondruš však dokazuje jeho používanie v slovienčine aj archaickej slovenčine ${ }^{61}$ a zároveň aj vysvetl'uje, prečo sa nevyskytuje v staroslovienčine. ${ }^{62}$

Staroslovienske termíny děd $\mathrm{b}$, otbcb $^{63}$ (otec $)^{64}$ sa v identických podobách vyskytovali už v praslovančine. Tieto slová vznikli z tzv. lalických slov, teda zo slov detskej reči, ${ }^{65} \mathrm{~s}$ charakteristickým opakovaním spoluhlásky ${ }^{66}$ (napr. „mama“, „papa“, „d’ad’a“) ${ }^{67}$ a nemajú etymologický základ v konkrétnom starobylom pôvodnom význame. Preto analýza termínu $o t b c b$ či dědb nemôže poslúžit’ na

množstvo pôvodných vel'komoravských miestnych názvov osád, ktoré reflektovali zamestnanecký charakter obyvatel'ov danej osady (Psiare, v obci žili chovatelia psov atd'.). Avšak takéto tvrdenie nie je možné použit' ako absolútny dôkaz proti tomu, že práve príslušníci rodu obývajúci danú osadu sa venovali konkrétnemu remeslu, ktoré neskôr inšpirovalo aj pomenovanie danej osady. Ak predpokladáme, že do takýchto osád prichádzali aj nie príslušníci rodín, aby sa tu „vyučili povolaniu“, a aj keby v osade zostali žit’ a pracovat’ ako „paholkovia“, stále v zmysle dobového obyčajového práva patrili pod zvrchovanú právomoc hlavy rodiny. Zastávame teda názor, že ak sa aj osady už vo vel'komoravskom období remeselnícky špecializovali, nemuselo to nevyhnutne znamenat úplný rozpad rodinných väzieb v osade.

60 LUBY, Štefan. Dejiny súkromného práva na Slovensku. Bratislava: IURA EDITION, 2002, s. 302. ISBN 8089047483.

61 MAJTÁN, ref. 37, s. 448.

62 Porovnaj ONDRUŠ, ref. 35, s. 34.

63 K podobám, aké má slovo „otec“v slovanských jazykoch pozri bližšie: MAŃCZAK, Witold. Przedhistoryczne migracje slowian pochodzenie jezyka staro-cerkiewno-slowiańskiego. Krakov: Pol'ská akadémia vied, 2004, s. 132. ISBN 8388857797.

64 KURZ, Josef. Učebnice jazyka staroslověnského. Praha: Slovenské pedagogické nakladatel'stvo, 1969, s. 49.

65 MACHEK, Václav. Etymologický slovník jazyka českého. Praha: ČSAV, 1957, s. 422.

66 HAVLOVÁ, Eva et al. Etymologický slovník jazyka staroslověnského. Diel 2. Praha: Academia, 1990, s. 127. ISBN 8020002227.

67 Vo východoslovanských jazykoch dodnes označenie pre strýka či iného mužského príslušníka rodiny rodičov. 
verifikovanie vyššie uvedeného postavenia hlavy rodiny. Je nutné analyzovat' iný termín, ktorým bola hlava rodiny označovaná z pozície iných príslušníkov rodiny: vhodným je slovo „svokor“, v staroslovienčine svekrb, ${ }^{68}$ svekry; ${ }^{69}$ takto bola hlava rodiny označovaná nevestami vydatými do rodiny. ${ }^{70}$ Tieto slová majú spoločný praslovanský základ *svekъrb, svekry a zároveň predpokladaný praindoeurópsky základ: *sveKuro-s, resp. *svelcur-o-s, pričom prvá čast' tohto slova sve označuje „,svoje“ a cur-o- „ktorý prináleži“ “" ${ }^{71}$ alebo „pán““. ${ }^{72}$ Spolu tieto slová znamenali, ten ktorý prináleží sám sebe (vol’nejšie preložené „sám sebe pánom“, „Zvrchovaný pán nad sebou“, „ten, ktorý nemá nad sebou iného pána“). ${ }^{73}$

V prípade rodinných čel'adí malo označenie svekъrъ s významom ,sám sebe pánom“ opodstatnenie: jedine hlava rodiny bola suverénom, ktorého rozhodovacej právomoci podliehali všetky osoby patriace do rodiny. Do rodiny patrili aj ženy do rodiny vydaté, pričom počas života otca boli aj nevesty pod primárnou právomocou otca rodiny; až po jeho smrti túto moc preberali jeho synovia. Význam termínu svektrt $\mathrm{v}$ podobe ten, kto je sám sebe vládcom, teda plne korešponduje s nazeraním na dominantné postavenie hlavy rodiny, ako ho podávajú dejiny.

Ako sme už uviedli, hlava rodiny bola označovaná aj termínom starešina alebo starosta. Koreňom oboch týchto termínov je základ starı vo význame starý. Druhým staroslovienskym slovom označujúcim starého bol termín vetbchъ vo význame chabého, vetchého starca. Naproti tomu termín starz bol používaný na označenie starého človeka $\mathrm{v}$ plnej sile, ktorý bol schopný zastávat' vedúce miesta v spoločnosti. O tom, že staroslovienčina dávala slovu starb vyššie naznačený význam, svedčia aj používané deriváty slova starb: starěišina. A práve slovo starěišina máme doložené aj v Nomokánon v dvoch prípadoch: „Ep(i) s(ko)p(o)mъ kogoždo jazyka věděti do/stoitb svojego starěišinu, iměti i jako gla$v u$. "Biskupi každého národa majú poznat' svojho starešinu a považovat' ho za

68 KURZ, ref. 64, s. 66.

69 HAUPTOVÁ, Zoe et al. Slovník jazyka staroslověnského. Diel 36. Praha: Academia, 1983, s. 25. ISBN 8020002944.

70 Jedná sa o slovo rovnomerne rozšírené v slovanských jazykoch. Vyskytuje sa v v nasledujúcich podobách: v pol'skom jazyku éwiekier, bulharčine svékár, srbochorvátčine spekrva, macedónčine svekor, srbochorvátčine svekar, slovenčine svokor, svokra a starej češtine svekr, svekruše, slovinčine sveker, ruštine svekróv, bieloruštine svekar, ukrajinčine svékor. Uvedené termíny majú významy manželov otec, svokor (otec manžela a manželky), výnimočne aj švagor. JANYŠKOVÁ, ref. 15, s. 904.

71 MACHEK, ref. 65, s. 595.

72 JANYŠKOVÁ, ref. 15, s. 904.

73 Relikt tohto praindoeurópskeho základu vraj možno nájst’ v Grécku, kde ženy oslovujú mužovho otca termínom „zvrchovaný pán“. Pozri bližšie: MACHEK, ref. 65, s. 595. Porovnaj s JANYŠKOVÁ, ref. 15, s. 904. 
svoju hlavu. ${ }^{74}$ „Ašte kotoryi ep(i)s(ko)pb s(vę)štenije ep(i)s(ko)pbsko priimet(b) i načerens starěišina byti. “ Ak niektorý biskup prijme biskupské svätenie, a je uctievaný ako predstavený l'udu.... ${ }^{75}$

Hoci v Nomokánone sa termín starešina vyskytoval len dvakrát, pri oboch týchto použitiach mal význam starešina - predstavený. $\mathrm{V}$ uvedených textových ukážkach má slovo starešina už mierne širší význam oproti pôvodnému označeniu hlavy rodiny/rodu. Slovo pôvodne označujúce hlavu rodiny - predstaveného $\mathrm{v}$ rode, bolo neskôr používané aj na označovanie hlavy alebo predstaveného inej jednotky/subjektu ako rodiny.

Podobný významový posun sa nám zachoval aj v archaickej slovenčine. ${ }^{76}$ Slovo starosta bolo pôvodne používané na označenie „,vrcholného predstaveného rodiny“, ktorá obývala ves/osadu. Neskôr, ked' v osadách stratili význam pokrvné zväzky a osady (neskôr obce) boli už len jednotkami územnej správy bez nevyhnutnej pokrvnej príbuznosti osôb ich obývajúcich, pôvodné označovanie hlavy rodiny starosta sa nad’alej používalo pre vrchného predstaveného v obci. ${ }^{77}$ Určitou obdobou významového posunu z označenia hlavy rodiny na označenie predstavitel'a územnej jednotky môže byt' aj archaické slovenské starší, obecný staršsi $^{78}{ }^{78}$ ako aj použitie slova starší s významom vyššie spoločensky zaradený úradný činitel'. ${ }^{79}$

Ďalším termínom, ktorým bola označovaná hlava rodiny (rodinného nedielu) bol dědr. Etymologický slovník jazyka staroslověnského uvádza, že derivátom tohto termínu je staroslovienske slovo dědbn' ${ }^{80}$ vo význame dedičná zem. ${ }^{81}$ Machek tvrdí, že dedina, teda majetok, ktorému vládne dědı, mal pôvodný význam rodového majetku, pozemkového majetku alebo nehnutel'ného majetku. S rovnakým významom sa používal aj archaický slovenský výraz dedina (majetok, grunt po dedovi). ${ }^{82}$ Derivátom slova děd z je aj slovo dedit', ktoré malo

74 Nomokanonъ 2, ref. 9, s. 264.

75 Nomokanonъ 10, ref. 9, s. 275.

76 MAJTÁN, ref. 37, s. 448.

77 Predstavitel' - velitel', starěišinbskb vladársky, vládcov, starěišinbstvovati vládnut'. JANYŠKOVÁ, ref. 15, s. 874.

78 „Pred zwrchu psanimy osobami a obecznimi starssimi strany teho...Ružomberok 1576. ...wsseczkich prisedicich stal se zapis a starssi nagprvsu tito. " Sliače, 1600. KUCHAR, ref. 38, s.112. Porovnaj s MAJTÁN, ref. 37, s. 444.

79 Tamže, s. 449.

80 Staroslovienčinou písané dokumenty vel'komoravského obdobia používali na označenie „dediny“ termín selo vo význame sídlo, statok. Podobná sémantická motivácia termínov dědbn'b a selo je teda zrejmá.

81 HAVLOVÁ, ref. 66, s. 127.

82 MAJTÁN, Milan (ed.). Historický slovník slovenského jazyka I. Bratislava: Slovenská akadémia vied, 1991. s. 238. ISBN 8022402281. 
v archaickej slovenčine význam dostat' dedovskú moc, neskôr získat' čokol'vek $\mathrm{z}$ dedovského majetku ${ }^{83} \mathrm{~S}$ rovnakými významami boli používané aj archaické slovenské výrazy dedičný, dedičit. ${ }^{84}$

Aj v prípade termínov děd z a starosta/starešina a z nich odvodených slov je teda možné predpokladat', že sa jednalo o termíny domáceho jazykového prostredia, ktoré už pred príchodom byzantskej misie boli dlhodobo používané. Nasvedčuje tomu ich relatívna ustálenost' používania aj v neskorších obdobiach.

Pre vytvorenie predstavy, ako fyzicky vyzerala ves môžeme použit' poznatky archeológie. Podl'a archeologických výskumov realizovaných na území Vel'kej Moravy mali vsi charakter otvorených osád, ktoré pozostávali z domov štvoruholníkového pôdorysu. Počet domov v osade málokedy prekročil desat'. Predpokladá sa, že v jednom dome mohli žit' tri generácie - rodičia, deti i prarodičia. Pri ideálnom stave mohlo žit' 6 jedincov v jednom dome. V takom prípade jedna vidiecka osada mala 40 až 60 obyvatel'ov. ${ }^{85}$ Práve informácia o predpokladanom približnom počte obyvatel'ov osady je pre nás relevantná, nakol'ko ju môžeme považovat' za potvrdzujúcu našu hypotézu, že ešte aj v období vel'komoravskom prevládali medzi obyvatel'mi vsi rodinné vzt'ahy: práve počet 40 - 60 obyvatel'ov môže byt' približným počtom, ktorý „,vel'ká rodina” (či rodinný nediel) obývajúca jednu ves mohla mat'.

\section{Zhrnutie poznatkov o miestnej správe}

Vychádzajúc z hypotézy, že v období prekladu Nomokánonu do staroslovienčiny vznikali územné jednotky cirkevnej správy podl’a vzoru pôvodnejších územných jednotiek miestnej správy predpokladáme, že termíny domáceho jazykového prostredia v Nomokánone obsiahnuté a použité na označenie územných jednotiek cirkevnej správy boli pôvodne používané na označenie jednotiek miestnej správy. Ak je tomu naozaj tak, tak po pokuse o identifikovanie názvov územných jednotiek miestnej správy na Vel'kej Morave sa môžeme pokúsit' o ich približné zaradenie do sústavy hierarchického usporiadania jednotiek miestnej správy v danom období.

83 MACHEK, ref. 65, s. 113.

84 MAJTÁN, ref. 82, s. 238.

85 IVANIČ, Peter. Západní Slovania v rannom stredoveku. Nitra: Univerzita Konštantína filozofa v Nitre - Filozofická fakulta, 2011, s. 30. ISBN 9788080949921; RUTTKAY, Alexander - RUTTKAY, Matej - ŠALKOVSKÝ, Peter. Slovensko vo včasnom stredoveku. Nitra: Archeologický ústav SAV, 2002, s. 69-80. ISBN 8088709601; ŠALKOVSKÝ, Peter. Dedinský dom a sídlo vo včasnom stredoveku. In Ludová architektúra a urbanizmus vidieckych sídiel na Slovensku z pohl'adu najnovšich poznatkov archeológie a etnografie. Eds. Juraj Botík, Peter Šalkovský, Matej Ruttkay. Bratislava: Academia Electronic Press, 1998, s. 9-36. ISBN 8088880262. 
Môžeme predpokladat', že najmenšou správnou jednotkou bola vbsb (ves, osada), v ktorej pravdepodobne ešte aj v mojmírovskom období prevládali medzi jej obyvatel'mi primárne príbuzenské vzt’ahy. ${ }^{86} \mathrm{Na}$ čele tejto jednotky stál starešina či starosta ako najstarší mužský predok či najstarší žijúci mužský príbuzný s rozsiahlou právomocou nad jemu podriadenými osobami.

Teritoriálne väčšou ${ }^{87}$ jednotkou bol gradı (hrad), ktorého základným znakom bolo ohradenie jeho územia drevo-zemným opevnením. V rámci neho s najväčšou pravdepodobnost'ou žili obyvatelia bez nevyhnutnosti príbuzenských väzieb. ${ }^{88}$ Hlavným predstavitel'om tu bol zrejme župan a inde knieža. ${ }^{89}$ Akým spôsobom hlavný predstavitel' gradu nadobudol svoju hodnost', sa na základe našich prameňov určit’ nedá. Vieme síce o existencii druhostupňových kniežat podiel'ajúcich sa s Mojmírovcami na moci, ${ }^{90}$ avšak odkial' sa táto aristokracia brala a aký bol zdroj ich moci a legitimity, či ako vôbec donútili obyvatel'ov, aby im spomínané grady postavili, vieme ešte menej, ako o nástupníckom systéme Mojmírovcov, čiže vlastne nič.

Okrem označenia starešina nám ako predstavitel' správy vystupuje aj označenie stolbnikъ. V texte Nomokánona sa tento termín nachádza len raz: stolbnika c(ě)s(a)rbstvujuščago $\operatorname{grad}(a)$ vo význame metropolita cisárskeho mesta (Nk XV, 284). Podotknime, že Metod výraz cisárske mesto použil pri preklade názvu Konštantínopol, išlo teda o najvyššieho predstavitel'a byzantskej cirkvi, o konštantínopolského patriarchu. Takáto funkcia však, samozrejme, na Morave neexistovala, týmto „stolníkom“ bol teda s najväčšou pravdepodobnost'ou Metod sám. V niektorých prácach sa síce predpokladá existencia stolníkov už v 9. storočí, ${ }^{91}$ ide však o neskoršie analógie z Uhorska. Nedá sa vylúčit', že v Nomokánone použil Metod výraz stolbnikъ ako pomerne všeobecný termín.

86 Uvedené konštatovanie však nie je verifikované.

87 Ale predpokladáme, že nie vyššou jednotkou v sústave hierarchického usporiadania jednotiek miestnej správy. K systému správnych jednotiek na Vel'kej Morave pozri bližšie napr. MESIARKIN, Adam. Veča. Príspevok k dejinám slovanského práva. In Historický časopis, 2016, roč. 64, č. 2, s. 333-360. ISSN 0018-2575.

88 Rozlišovanie vbsi a gradba malo význam aj v práve Vel'kej Moravy. Zákonník obsahoval ustanovenie, ktoré ukladalo rozdielne tresty podl'a toho, či protiprávne konanie sa udialo v grade, alebo vo vbsi.

89 Ref. 3.

90 HAVLÍK, Lubomír E. Slovanské státni útvary raného středověku. Politické postavení, společenská a vládni organizace státnich útvarů ve východní, středni a jihovýchodni Evropě od 8. do 11. století. Praha: Academia, 1987, s. 75. HAVLÍK, ref. 4, s. 65; TŘEŠTíK, Dušan. Počátky Přemyslovců. Vstup Čechů do dějin (530 - 935). Praha: Nakladatelství Lidové noviny, 1997, s. 288; STEINHÜBEL, ref. 7, s. 229-230; LYSÝ, ref. 29, s. 127-129.

91 SOKOLOVSKÝ, Leon. Prehl'ad dejín verejnej správy na územi Slovenska. I. čast' (Od počiatkov do roku 1526). Bratislava : Metodické centrum mesta Bratislavy, 1995, s. 14. 
Staroslovienskym termínom strana sa v Nomokánone označovali jednak územia „ležiace stranou“, ale aj vidiek, teda tiež územia ležiace mimo mestá, mimo hlavné centrá. Ak Nomokánon reflektuje vel'komoravskú realitu pomenovávania oblastí mimo miest (mimo gradov), termínom strana by sme mohli označit' územie zahŕňajúce okolie miest, okolité vbsi pravdepodobne nevynímajúc. Predpokladáme, že týmto termínom sa pravdepodobne neoznačovala konkrétna územná jednotka, ktorú by sme mohli zaradit' do systému hierarchického usporiadania územných jednotiek miestnej (či cirkevnej) správy.

Staroslovienskymi termínmi oblastb a strojenije boli v texte Nomokánona najčastejšie označované jednotky cirkevnej správy, ktoré môžeme nazvat' eparchia/diecéza. Predpokladáme, že termínmi oblastb a strojenije sa označovala jedna a tá istá jednotka miestnej správy, a že sa nejednalo o rozdielne územné jednotky (termínom strojenije sa označovala nielen samotná územná jednotka, ale aj jej hranice. Rovnako sa termínom strojenije označoval aj výkon správy nad touto jednotkou). Termínom oblastb bola v menšej miere označovaná aj právomoc nad danou územnou jednotkou. Ako určitú paralelu s označovaním hranice (medze) a vymedzením spravovania záležitostí v dnešnom jazyku môžeme uviest' slovné spojenie ,vymedzit' právomoci“. Slovo medza je dodnes dobre zrozumitel'né ako ohraničenie niečoho a v mad'arčine, pod vplyvom slovanského jazykového prostredia bol označovaný územný obvod hradského komitátu a potom šl'achtickej stolice termínom megye. ${ }^{92}$

Ak aj v tomto prípade autor Nomokánona vzal za predlohu správy cirkevných záležitostí už existujúcu miestnu správu (svetských) záležitostí, možno predpokladat', že termínmi oblastb a strojenije sa nazývali väčšie územia, niekedy nepresne označované v historickej spisbe ako župy. Mätúce pritom môže byt', že na označenie jednej územnej jednotky sa používali dva rozdielne termíny. Uvedená skutočnost' však mohla byt' spôsobená tým, že v mojmírovskom období ešte nebola ustálená správna terminológia a na jeden pojem sa používali aj dva, či tri termíny. ${ }^{93}$

92 ONDRUŠ, ref. 35, s. 35. K otázkam kontinuity či diskontinuity medzi Vel'kou Moravou a ranofeudálnym Uhorskom porovnaj LUKAČKA, Ján. Čo zostalo z cyrilo-metodského dedičstva a vel'komoravského krest'anstva v 10. storočí? (k problematike kontinuity vel'komoravského a včasnouhorského krest’anstva). In Tradicia a prítomnost' misijného diela sv. Cyrila a Metoda. Nitra: UKF, 2013, s. 163-177. ISBN 97880558041019; LUKAČKA, Ján. Kontinuita či diskontinuita cyrilo-metodského krest’anstva a tradície. In MARTÍNEK, Peter - NOGOVÁ, Mária - HUBAČ, Marián (eds.). Vzdelávanie - súčast' misie svätých Cyrila a Metoda. Bratislava: Metodicko-pedagogické centrum, 2014, s. 34-37. ISBN 9788080526108.

93 Neustálenost' terminológie bola charakteristickým javom aj archaickej slovenčiny používanej na záznam listín v Uhorsku. K uvedenej problematike pozri napr. JÁGER, Róbert. Premeny termínu právo v slovanskom jazykovom prostredí. In Právny poriadok Slovenskej republiky po 25. rokoch - aktuálne výzvy. Banská Bystrica: Belianum, 2016, s. 229-243. 


\section{ZUR SPRACHE DER ÖRTLICHEN VERWALTUNG \\ NACH DER ALTSLAWISCHEN NOMOKANON ÜBERSETZUNG}

\section{RÓBERT J Á GE R - MIROSLAV LY S Ý}

Zur Sprache der örtlichen Verwaltung nach der altslawischen Nomokanon Übersetzung. Der vorgebrachte Beitrag ist ein Versuch der Rekonstruktion von Bezeichnungen und System der örtlichen Verwaltung in dem Mojmirischen Mähren. Diese Rekonstruktion verwirklichten wir auf Grundlage der Analyse von altslawischer Nomokanon Übersetzung. Nomokanon widmete sich in seinen Normen der kirchlichen Verwaltung, wir gehen jedoch von der Voraussetzung der Spracheeinheitlichkeit für kirchliche und örtliche Verwaltung aus. Diese Voraussetzung unterstützt auch die Tatsache, dass die im Nomokanon benutzten Termini direkte Übersetzung waren und wir fanden ihre Parallelen auch in anderen altslawischen Texten, wonach in der Studie ebenso verwiesen wird. Die Aufmerksamkeit wird besonders den Termini oblastь, strojenije, predělı, gradъ, město, vbsь, strana gewidmet. Es wird gezeigt, in welchem Kontext diese Termini benutzt wurden und in einigen Fällen bemühen wir uns, Analogien auch in anderen Sprachen zu finden, um auf die Zusammenhänge der Übersetzung von Methodius hinzudeuten. Anschließend versuchen wir, diese Gebietseinheiten im System der örtlichen Verwaltung und deren Anordnung in der vorgesehenen hierarchischen Struktur auch mit der hypothetischen Beschreibung deren eventuellen Verwaltung zu identifizieren.

Doc. JUDr. PhDr. Róbert Jáger, PhD.

Ondrašovská 50/413, Liptovský Mikuláš, 03105

Katedra dejín štátu a práva, Právnická fakulta Univerzity Mateja Bela v Banskej Bystrici

Komenského 20, Banská Bystrica

Slovenská republika

e-mail: robert.jager@umb.sk

Doc. Mgr. Miroslav Lysý, PhD.

Katedra právnych dejín a právnej komparatistiky, Právnická fakulta Univerzity Komenského v Bratislave

Šafárikovo nám. č. 6, P.O.BOX 313, 81000 Bratislava

Slovenská republika

e-mail: miroslav.lysy@flaw.uniba.sk

ISBN 9788055710730. 